\title{
SCĂDEREA NIVELULUI DE EMISII POLUANTE PRIN UTILIZAREA TEHNOLOGIEI DE TRATARE A DEȘEURILOR PRIN GAZEIFICARE
}

REDUCING THE LEVEL OF POLLUTANT EMISSIONS THROUGH WASTE TREATMENT TECHNOLOGY WITH GASIFICATION

ing./eng. Cristian Lungu SC EOSOL DESIGN SRL

cristianvlungu@gmail.com 


\title{
Rezumat
}

Lucrarea de față prezintă o nouă posibilitate de tratare a deșeurilor municipale sortate folosind tehnologia gazeificării.

Sunt indicate trei căi de reducere a emisiilor toxice care se pot implementa într-un asemenea sistem: gazeificarea la temperatură înaltă, arderea gazului de sinteză la peste $1300^{\circ} \mathrm{C}$ și filtrarea gazelor arse cu două sisteme de filtrare montate în serie.

Metoda are eficiență ridicată doar în cazul deșeurilor sortate, unde proporția de produse de plastic și deșeuri electrice/electronice, însumate, reprezintă sub $15 \%$ din total deșeuri utilizate pentru gazeificare.

Cuvinte cheie: gazeificare, deșeuri, filtrare

\begin{abstract}
The present paper deals with a new possibility of treating sorted municipal waste through gasification technology. There are indicated three ways of reducing the toxic emissions that can be used for such a system: high temperature gasification, syngas burning at a temperature higher than 1,300 degrees $\mathrm{C}$ and flue gas filtration by means of two filtration systems connected in series.

The method is highly efficient only when used for sorted waste, in which the percentage of both plastic materials and electrical/electronic waste is $15 \%$ out of the totl amount of waste used for gasification
\end{abstract}

Keywords: gasification, waste, filtration 
Valorificarea deșeurilor municipale este o preocupare care devine tot mai presantă, pe măsură ce cantitatea de deșeuri crește într-un ritm accelerat.

Prima formă de valorificare a fost sortarea deșeurilor pe câteva categorii (hârtie, plastic, PET, metale, sticlă) și reciclarea acestora. Ce rămâne după această sortare este aruncat la groapa de gunoi. Ponderea acestor resturi poate ajunge, în funcție de sezon, până la $50 \%$ din total deșeuri municipale.

Deși s-au făcut investiții foarte mari în ecologizarea gropilor de gunoi, problema poluării provocate de către acestea la nivelul aerului, pământului și pânzei freatice rămâne un subiect spinos pe agenda agențiilor de mediu din lumea întreagă.

Una dintre metodele propuse este valorificarea energetică a acestor deșeuri, prin utilizarea tehnologiei gazeificării. Cel mai cunoscut procedeu de gazeificare a deșeurilor este gazeificarea cu plasmă. Această soluție tehnică are două mari dezavantaje: are costuri foarte ridicate, iar bilanțul energetic este foarte slab pozitiv sau chiar negativ.

Avantajul incontestabil, însă, posibilitatea realizării de temperaturi foarte înalte la care se realizează gazeificarea. Este cunoscut faptul că, la temperaturi de peste $1300^{\circ} \mathrm{C}$, nu se mai formează compușii chimici toxici, de tip furani și dioxine. Din punctul de vedere al depoluării, gazeificarea cu plasmă rămâne un element de referință.

O altă soluție tehnică care să permită gazeificarea deșeurilor, fără a mai exista pericolul emisiilor de furani sau dioxine, este gazeificarea la o temperatură de $1200^{\circ} \mathrm{C}$, urmată de arderea syngas-ului la temperaturi de peste $1300^{\circ} \mathrm{C}$ și filtrarea gazelor de ardere rezultate cu ajutorul a două sisteme de filtrare diferite montate în serie. Această soluţie are un cost de implementare mai redus decât plasma și un bilanț energetic pozitiv.

O astfel de centrală în cogenerare, care include și linia de sortare deșeuri, are următoarele componente principale (Fig. 1):

1. Platformă de descărcare deșeuri

2. Linie sortare deșeuri

3. Tocător

4. Uscător rotativ

5. Gazeificator

6. Schimbător de căldură, pentru încălzire agent termic

7. Grup generator tip ORC, cu circuit închis

8. Schimbător de căldură, pentru răcire agent termic

9. Radiatoare

10. Sistem filtrare chimică

11. Sistem filtrare în plasmă rece, folosind tehnologia GlidArc.

Acest tip de centrală nu are dotări pentru recuperarea metalelor din deșeuri.

Pentru a putea obține o gazeificare la $1200^{\circ} \mathrm{C}$ se folosește un gazeificator dublu corp.

Primul corp este orizontal, rotativ și reprezintă gazeificatorul propriu-zis. Cel de-al doilea corp este vertical, fix și reprezintă zona de ardere a syngas-ului.

Ambele corpuri sunt realizate din tablă de oțel și sunt căptuşite la interior cu un ciment refractar care are o grosime de 200mm (Fig. 2).

Acest tip de gazeificator este produs de către firma ASTE Ltd. din Grecia, iar performanţele și fiabilitatea acestui concept sunt dovedite în peste 20 de ani de exploatare. 
Municipal waste valorization process is more and more pressing as the amount of waste is ever increasing.

A first step in valorization was to separate waste into type materials (paper, plastic, PET, metals, glass) and recycle them. What remains after this sorting is thrown in the landfill. Depending on the season, these leftovers may represent $50 \%$ from the total amount of municipal waste.

Although large investments were made in the ecologization of landfills, they still provoke air, land and ground water pollution -a problem which remains a sensitive topic on the agenda of environment agencies worldwide.

One of the methods presented is the energetic valorization of waste, by means of gasification technology. The most known process of waste gasification is plasma gasification. This technical solution has two major disadvantages: excessive costs and the energetic balance is weakly positive, or even negative.

But there is an undeniable advantage - the possibility of obtaining very high temperatures for gasification. It is well known that at temperatures higher than $1300 \mathrm{O}$, toxic chemical compounds such as furans and dioxins do not form any longer.

Another technical solution which allows waste gasification, eliminating the danger of furans or dioxins emissions, is gasification at a temperature higher than $1200 \mathrm{o} C$, followed by syngas burning at temperatures higher than $1300 \mathrm{o} C$ and filtering of the flue gas resulted from combustion via two different filtration systems connected in series. As compared to plasma system, this solution offers the advantage of lower costs and a positive energetic balance.

This type of cogeneration power plant, which includes also a waste sorting line, has the following components (Fig. 1):

12. waste download platform

13. waste sorting line

14. shredder

15. rotary dryer

16. gasifier

17. heat exchanger, for thermal agent heating

18. ORC power generator, with closed circuit

19. heat exchanger, for thermal agent cooling

20. radiators

21. chemical filtering system

22. cold plasma filtering system, by using GlidArc technology

This type of power plant is not provided with equipments for waste metal recovery

A double - bodied gasifier is used for gasification at $1200^{\circ} \mathrm{C}$.

The first body is horizontal, rotary and represents the gasifier itself. The second body is upright, fixed and represents the syngas combustion chamber.

Both these bodies are made of steel sheet and are coated inside with a $200 \mathrm{~mm}$ thick layer of refractory concrete (Fig. 2).

This type of gasifier is produced by ASTE Ltd. Company based in Greece; the reliability and performance of this concept have been proved in more than 20 years of utilization. 

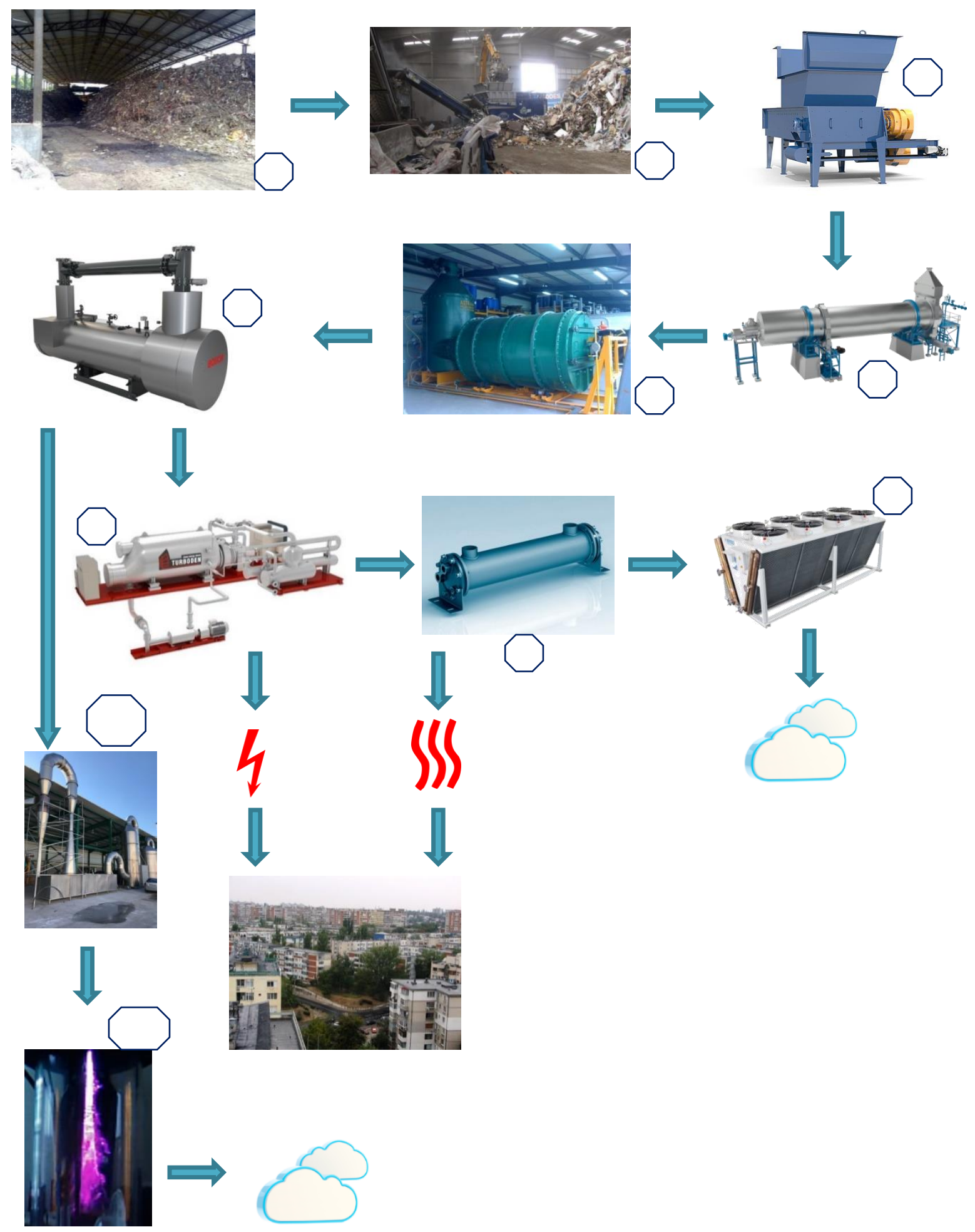

Fig. 1: Sursa/Source: EOSOL DESIGN, Romania 


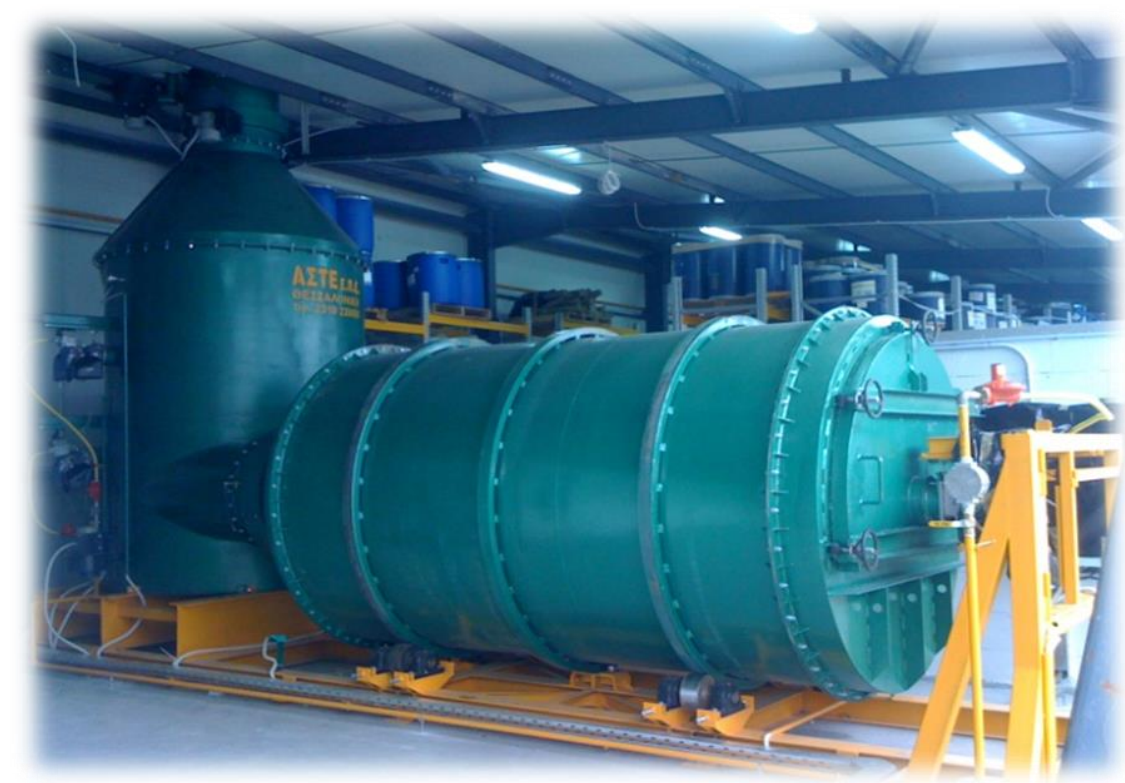

Fig. 2: Sursa/Source: ASTE Ltd, Grecia

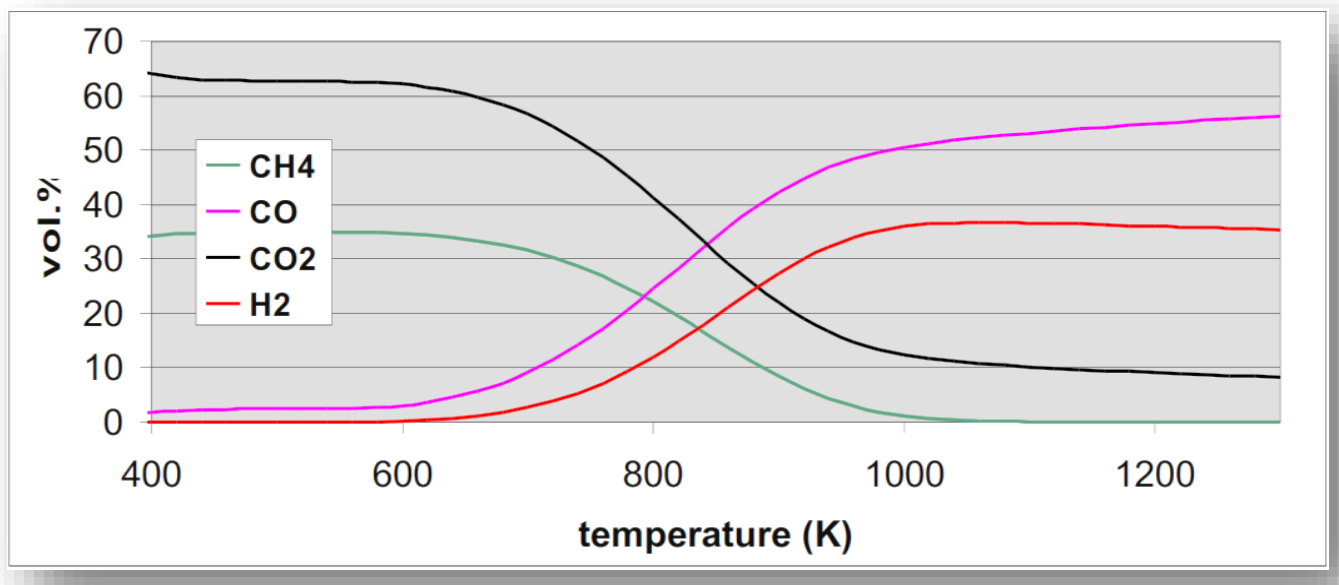

Fig. 3: Sursa/Source: Unicorn Power Ltd, Great Britain.

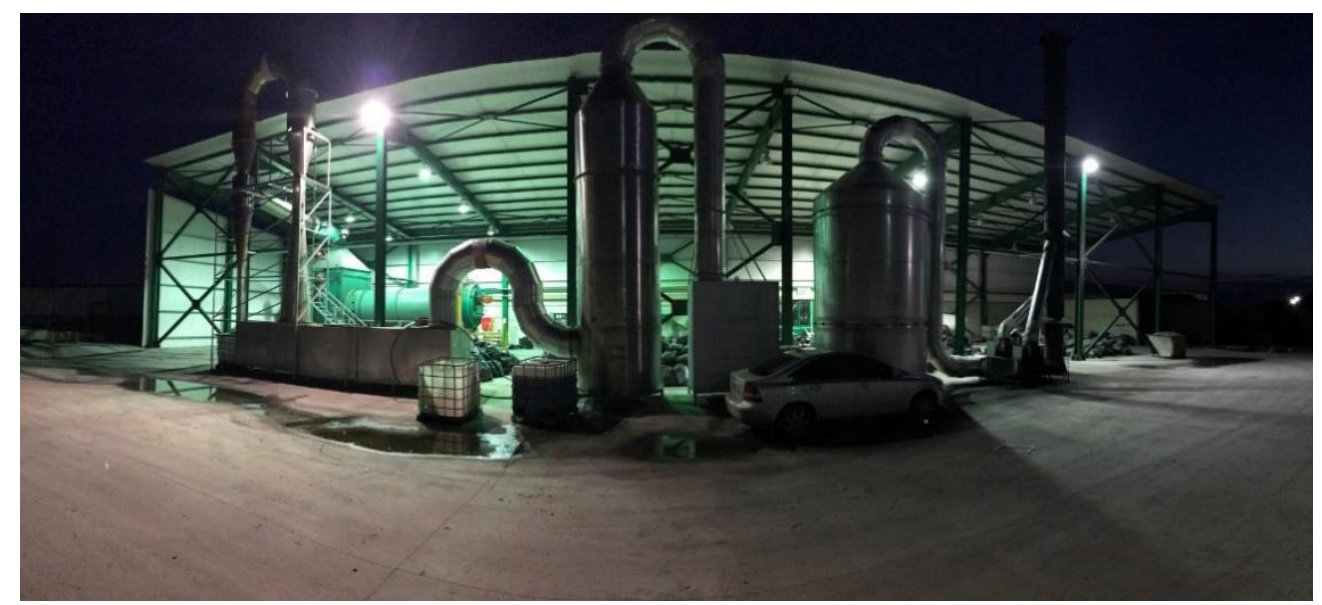

Fig. 4: Sursa/Source: ASTE Ltd, Grecia 
Gazeificatorul este capabil să funcționeze continuu și stabil la orice temperatură aflată în intervalul $400^{\circ} \mathrm{C}-1200^{\circ} \mathrm{C}$.

Arderea syngas-ului se face la temperaturi de peste $1300^{\circ} \mathrm{C}$ pentru a evita apariția furanilor și a dioxinelor.

Amorsarea gazeificatorului se face cu ajutorul unui arzător cu gaz metan. După amorsare, deșeurile (tocate, uscate și cântărite în prealabil) sunt introduse în corpul orizontal unde începe procesul de gazeificare.

La acest tip de gazeificator alimentarea cu deșeuri nu este de tip continuu, ci este de tip secvenţial.

Datorită temperaturii înalte din gazeificator, procesul de gazeificare al deșeurilor nou introduse demarează în maxim 2 minute.

Injecția de aer este limitată permanent la nivelul minim necesar auto-întreținerii procesului de gazeificare.

Așa cum se cunoaște, gazul de sinteză rezultat are în componența sa patru compuși principali: $\mathrm{H}_{2}, \mathrm{CO}, \mathrm{CO}_{2}$ și $\mathrm{CH}_{4}$, a căror pondere variază funcție de temperatura de gazeificare (fig. 3).

Pe lângă acești compuși de bază apar, cu ponderi mici și variabile, și compuși de tip dioxine, furani, HCl, HF. Pentru neutralizarea dioxinelor și furanilor este folosită metoda arderii gazului de sinteză la temperaturi de peste $1300^{\circ} \mathrm{C}$. Această ardere se realizează în corpul vertical unde se exploatează faptul că syngas-ul abia ieșit din corpul orizontal are deja o temperatură de $1200^{\circ} \mathrm{C}$. Arderea gazului ridică temperatura acestuia până în jurul valorii de $1380^{\circ} \mathrm{C}$, suficient pentru eliminarea dioxinelor și furanilor.

Imediat ce ies din corpul vertical, gazele sunt introduse în schimbătorul de căldură unde este încălzit uleiul termic pentru generatorul ORC (fabricat de către TURBODEN, Italia).

După ce au părăsit schimbătorul de căldură, gazele de ardere sunt răcite, trecute printrun filtru ciclon (pentru îndepărtarea particulelor solide), apoi sunt dirijate către primul sistem de filtrare. Acesta este de tip uscat și este identic, ca principiu, cu cel folosit la centralele de incinerare a deșeurilor, având ca element activ $\mathrm{CaO}$ (fig. 4). Având un principiu clasic de funcționare, deja foarte cunoscut, acest sistem de filtrare nu va fi detaliat în această lucrare.

După ce trece de sistemul de filtrare, gazul de sinteză parcurge un sistem suplimentar de filtrare, denumit PARS (Plasma Assisted Reforming Scrubber), care folosește tehnologia GlidArc (Fig. 5).

Filtrul PARS a fost dezvoltat atât de cercetători americani, cât de cercetători europeni, printre care și de prof. Albin Czernichowski, de la Universitatea din Orleans, Franța.

Varianta constructivă, care este folosită în cadrul acestei lucrări și care a fost pusă la punct de către prof. A. Czernichowski, se numește SulfArc și are ca scop neutralizarea

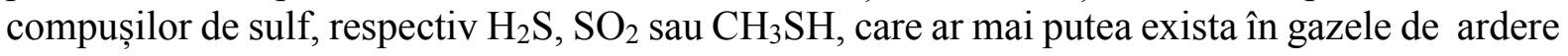
după ce au trecut de primul sistem de filtrare.

Acest dispozitiv a fost făcut public în lucrarea "GlidArc-assisted removal and/or upgrading of Hydrogen Sulfide or Methyl-Mercaptan", din 2003. ${ }^{2}$

Schema acestui filtru este redată în Fig. 6. 
The gasifier can run continually and is stable at any temperature in the range $400^{\circ} \mathrm{C}-$ $1200^{\circ} \mathrm{C}$.

Syngas burning takes place at temperatures higher than $1300^{\circ} \mathrm{C}$ in order to prevent furans and dioxins formation.

The gasifier is heated by means of a methane gas burner. Then the solid waste (which was shredded, dried and weighted) is fed into the horizontal body of the gasifier where the gasification process starts.

For this type of gasifiers, the feeding system is not continuous, it is sequential.

Due to the high temperature in the gasifier, the gasification process of a new amount of waste materials fed starts within 2 minutes.

Air injection is permanently restricted at a minimum level necessary for the gasification process to self-maintain.

As it is known, the resulted syngas has four main components: $\mathrm{H}_{2}, \mathrm{CO}, \mathrm{CO}_{2}$ and $\mathrm{CH}_{4}$ which are represented in a variable percentage depending on the gasification temperature (fig. $3)$.

Besides these basic components there are, in small and variable amounts, also components similar to dioxins, furans, HCL, HF. In order to neutralize dioxins and furans, the method of burning syngas at temperatures higher than $1300^{\circ} \mathrm{C}$ is used. This burning process occurs in the vertical body where the syngas that comes directly from the horizontal body has alredy a temperature of $1200^{\circ} \mathrm{C}$. The process of burning raises the temerature of the syngas up to almost $1380^{\circ} \mathrm{C}$, which is an adequate value for furans and dioxins removal.

At the very moment of their exiting from the vertical body, the flue gases are directed to the heat exchanger where the thermal oil is heated for the ORC generator (produced by TURBODEN, Italy).

After coming out from the heat exchanger, the flue gases are cooled, passed through a cyclone filter (for removing the solid particles), then they are funneled towards the first filtering system. This is a dry system and is identical, in principle, with the ones used at waste incineration plants, having as an active component $\mathrm{CaO}$ (fig. 4). Having a classical operating principle, already well known, this type of filtering system will not be detailed in this paper.

After passing through the filtering system, syngas passes through an additional filtering system called PARS (Plasma Assisted Reforming Scrubber), based on GlidArc technology (Fig.5)

PARS filter was developed by both American and European researchers, among whom there is also professor Albin Czernichowski from the University of Orleans, France.

The constructive variant described in this paper and settled by professor A. Czernichowski is called SulfArc and was aimed at neutralizing sulphur compounds, that is $\mathrm{H}_{2} \mathrm{~S}$, $\mathrm{SO}_{2}$ or $\mathrm{CH}_{3} \mathrm{SH}$ respectively, which could still exist in the fuel gas after it passes through the first filtering system.

This device was drawn to the public attention through the paper "GlidArc-assisted removal and/or upgrading of Hydrogen Sulfide or Methyl-Mercaptan" in 2003

The diagram of the filter is shown in Fig. 6. 


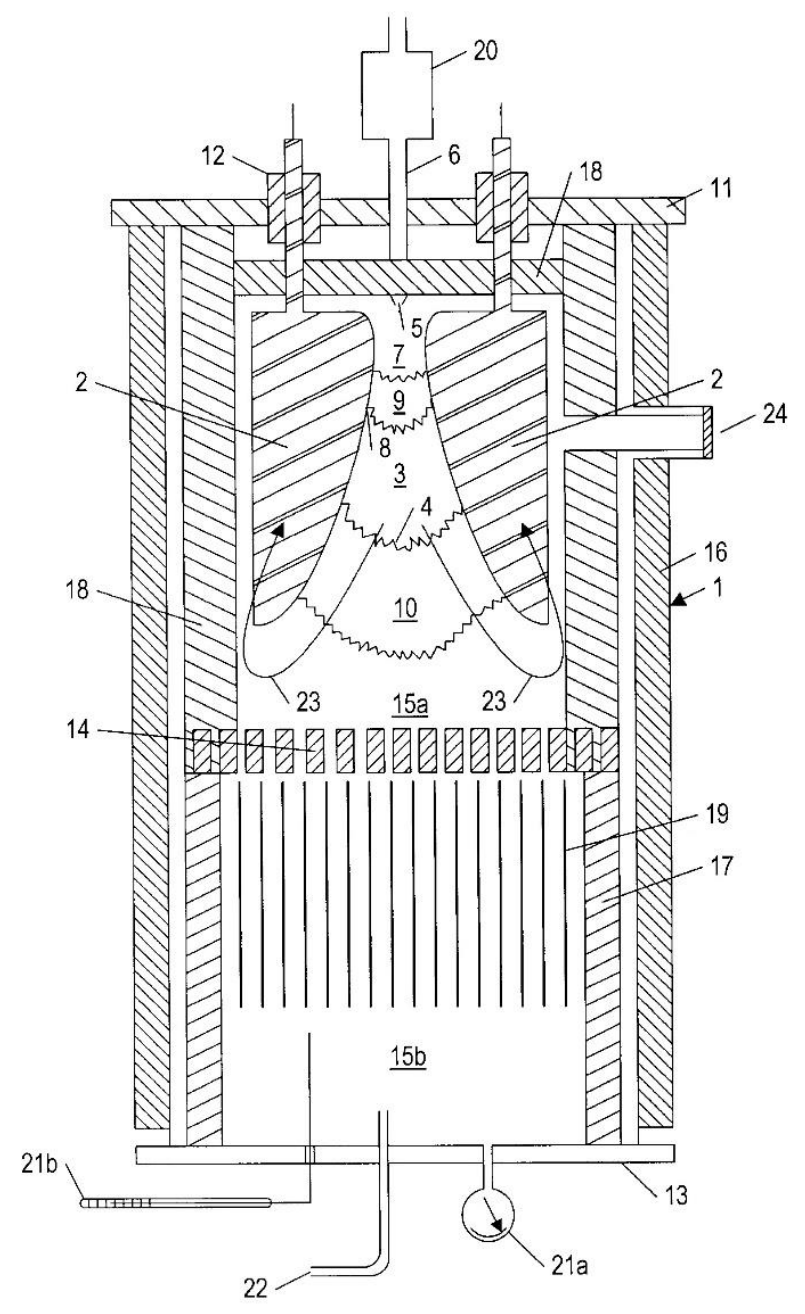

Fig. 5: Sursa/Source: US Patent 6,007,742

Reacțiile care au loc în acest sistem, așa cum au fost prezentate de prof. A. Czernichowski, sunt următoarele:

$$
3 \mathrm{H}_{2} \mathrm{~S}+1,5 \mathrm{O}_{2}=2 \mathrm{H}_{2} \mathrm{~S}+\mathrm{SO}_{2}+\mathrm{H}_{2} \mathrm{O}=3 \mathrm{~S}+3 \mathrm{H}_{2} \mathrm{O} \text {. }
$$

Eficiența acestui filtru este foarte ridicată, făcându-l un element de nelipsit în orice instalație de filtrare a gazelor care conțin compuși de sulf.

Combinația celor trei sisteme, gazeificator - sistem filtrare chimică - sistem filtrare tip PARS, se dovedește eficientă în reducerea emisiilor poluante care apar în timpul procesului de valorificare a deșeurilor municipale sortate.

Performanța soluțiilor tehnologice integrate, capacitatea de interconectare și scalabilitatea fac din acest tip de centrală una dintre cele mai fiabile și ușor de integrat soluții, cu un randament energetic bun și cu o perioadă scurtă de implementare. 


\section{Exit gas}

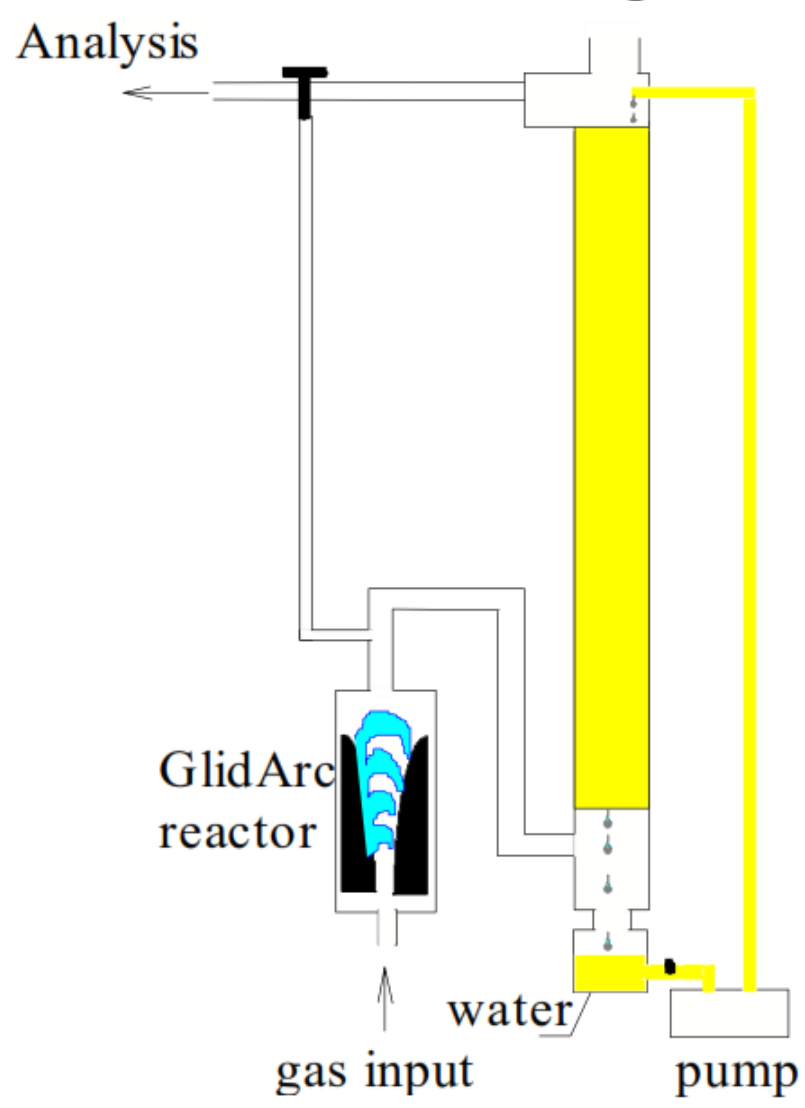

Fig. 6: Sursa/Source:http://albin.czernichowski.pagesperso-orange.fr/ECP/SulfArc-.htm

The reactions that take place in this system, as they were presented by professor A. Czernichowski are the following:

$$
3 \mathrm{H}_{2} \mathrm{~S}+1,5 \mathrm{O}_{2}=2 \mathrm{H}_{2} \mathrm{~S}+\mathrm{SO}_{2}+\mathrm{H}_{2} \mathrm{O}=3 \mathrm{~S}+3 \mathrm{H}_{2} \mathrm{O} \text {. }
$$

This filter has a high efficiency, which makes it highly functional in any gas filtering installation with sulphur compounds.

The combination of the three systems gasifier- chemical flitering system - PARS type filtering system proves to be very efficient in reducing polluting emissions generated during the valorization of the sorted municipal waste

The performance of the integrated technological solutions, the interconnection capacity and scalability make this power plant one of the most reliable and easy-to-integrate solutions, with a highly positive energetic performance and with a short implementation period. 


\section{Referinţe/References}

Czernichowski, A. (2003). „GlidArc-assisted removal and/or upgrading of Hydrogen Sulfide or Methyl-Mercaptan“, $16^{\text {th }}$ Int. Symp. on Plasma Chemistry, Taormina, Italy, June 2227, 2003

\section{Referinţe web/Web references}

http://albin.czernichowski.pagesperso-orange.fr/ 